\title{
HUBUNGAN ANTARA PENGGUNAAN TEKNOLOGI MEDIA BK DENGAN KEPUASAN LAYANAN BIMBINGAN KLASIKAL
}

\author{
Ayu Oga Artiani ${ }^{1}$, Nur Aeni Sanjaya ${ }^{2}$ \\ Universitas Islam Negeri Sunan Kalijaga Yogyakarta \\ ayuoga911@gmail.com1,nuraenisanjaya16@gmail.com2
}

Received :

; Accepted :

; Published :

\begin{abstract}
This study aims to determine the relationship between the use of media technology guidance and counseling and the satisfaction of classical guidance services of class VIII MTs Negeri 6 Sleman using a quantitative approach. The independent variable in this research is the use of media technology guidance and counseling $(X)$, while the dependent variable is the satisfaction of classical guidance services $(Y)$. This study is a research with 63 student respondents. The main data collection techniques are scale, while interviews and documentation are supplementary data. Data analysis using Product Moment correlation study from Pearson to obtained the results of hypothesis testing, with the help of SPSS 16.0 for Windows. The results of this research indicate that there is a positive and highly significant relationship between the use of media technology guidance and counseling with the satisfaction of classical guidance services of class VIII MTs Negeri 6 Sleman which has a correlation coefficient of 0.406 with sig. (2-tailed) $=$ 0.001 with $N=63$ at 1\% significance level. From these data it can be concluded that there is a positive relationship and very significant, then the hypothesis is accepted and proved true. Therefore, the higher the use of media technology guidance and counseling, the higher the satisfaction of classical guidance services. On the contrary, if it gets lower the use of media technology guidance and counseling, the lower the satisfaction of classical guidance services.
\end{abstract}

Keywords: Use of Media Technology Guidance and Counseling, Satisfaction of Classical Guidance Services.

Pendidikan adalah proses perubahan atau pendewasaan manusia, berawal dari tidak tahu menjadi tahu, dari tidak bisa menjadi bisa, dari tidak paham menjadi paham, dan sebagainya. Pendidikan itu bisa didapatkan dan dilakukan di mana saja, bisa di lingkungan sekolah. Sekolah adal ah salah satu lembaga pendidikan yang harus memberikan fasilitas guna mengembangkan potensi yang dimiliki oleh setiap siswanya. Sekolah sebagai lembaga pendidikan formal merupakan tempat dilaksanakannya tugastugas pendidikan yang diarahkan untuk pencapaian tujuan pendidikan. Tujuan ini 
akhirnya menghasilkan sumber daya manusia yang baik, memiliki pengetahuan, keterampilan dan sikap positif.

Teknologi media saat ini sangat penting dipelajari dan dikuasai oleh masyarakat terlebih dalam bidang pendidikan. Dengan menggunakan teknologi media ini dapat lebih cepat mengakses informasi secara global sehingga mempermudah dalam melakukan pekerjaan. Perkembangan teknologi media akhir-akhir ini sangatlah diunggulkan dengan seiring maraknya muncul berbagai bentuk teknologi yang semakin canggih. Perkembangan ini apabila tidak diimbangi dengan sumber daya manusia yang berpikir maju maka akan sia-sia saja kemunculannya. Selain itu, masyarakat dalam menggunakan teknologi media harus pintar mengolah dan memilahnya. Dalam teknologi media tidak sedikit terdapat unsur negatif di dalamnya. Terlebih lagi yang kita ketahui bersama, kebutuhan akan teknologi media bukan hanya di masyarakat saja, namun dalam bidang pendidikan khususnya sekolah.

Di sekolah, jelas sangat membutuhkan teknologi media untuk membantu guru dalam proses pembelajaran. Ketika seorang guru mengajar di kelas menggunakan bantuan teknologi media maka akan menarik perhatian siswa dalam kegiatan belajar mengajar, tidak terkecuali dengan guru bimbingan dan konseling. Guru bimbingan dan konseling juga sangat membutuhkan teknologi media untuk membantu proses layanan bimbingan dan konseling.

Layanan bimbingan dan konseling di sekolah sering diartikan hanya untuk menangani siswa yang bermasalah saja, lebih dari itu bimbingan dan konseling berfungsi untuk membantu siswa yang kesulitan belajar dan masalah pribadinya. Dalam kaitannya dengan teknologi media, layanan bimbingan dan konseling juga memanfaatkan teknologi media. Layanan ini tidak harus dilakukan dengan proses tatap muka, namun dengan memanfaatkan teknologi media proses bimbingan dan konseling dapat lebih menarik, interaktif, dan tidak terhambat oleh ruang dan waktu.

Kenyataan menunjukkan bahwa masih banyak siswa yang merasa belum puas terhadap layanan bimbingan klasikal. Kepuasan adalah perihal yang bersifat puas, kesenangan, kelegaan dan sebagainya. Kepuasan siswa adalah suatu sikap yang diperlihatkan oleh siswa, baik sikap positif maupun sikap negatif atas adanya kesesuaian antara harapan mereka terhadap pelayanan proses belajar mengajar yang diterimanya. Jika apa yang didapatkan siswa sesuai dengan apa yang diharapkan maka siswa akan merasa puas, dan jika apa yang diterima siswa tidak sesuai, maka siswa akan merasa tidak puas. 
Banyak guru bimbingan dan konseling yang masih belum maksimal dalam memanfaatkan teknologi media, sehingga tidak jarang siswa merasa bosan mengikuti layanan bimbingan klasikal. Hal ini diharapkan dengan memanfaatkan teknologi media yang digunakan oleh guru bimbingan dan konseling dapat membantu mengatasi masalah belajar siswa. Penggunaan teknologi media dapat memengaruhi kepuasan siswa dalam layanan bimbingan klasikal.

Seperti penelitian yang dilakukan oleh Ali Lukmanul Hakim Program Studi Manajemen Pendidikan Fakultas Ilmu Tarbiyah dan Keguruan Universitas Islam Negeri Syarif Hidayatullah Jakarta pada tahun 2014 yang berjudul "Kepuasan Siswa terhadap Layanan Bimbingan Konseling di SMK Al-Hidayah Lestari Lebak Bulus" membahas mengenai tingkat kepuasaan siswa terhadap layanan bimbingan konseling di SMK AlHidayah Lestari Lebak Bulus masih berada pada taraf rendah. Metode penelitian yang digunakan adalah metode deskriptif dengan pendekatan kuantitatif, yaitu untuk menganalisis dan menafsirkan data berkenaan dengan fakta, keadaan dan fenomena yang terjadi saat penelitian berlangsung. Sumber data penelitian menggunakan penyebaran angket dan wawancara. Hasil penelitian menunjukkan bahwa nilai layanan bidang akademik sebesar $23,80 \%$, layanan bidang pribadi sosial sebesar $13,75 \%$, dan layanan bidang karir sebesar $34,21 \%$. Kepuasan siswa terhadap layanan bimbingan konseling secara keseluruhan berada pada taraf sangat rendah atau tidak memuaskan dengan nilai rata-rata $22,28 \%$. Dengan demikian tingkat kepuasan siswa terhadap layanan bimbingan konseling di SMK Al-Hidayah Lestari Lebak Bulus masih berada pada taraf sangat rendah, sehingga perlu ditingkatkan lagi.

Pencapaian kepuasan siswa memang memiliki perbedaan dari siswa satu dengan siswa lainnya. Apabila diberikan semaksimal mungkin, maka akan mencapai kepuasan siswa yang tinggi. Kepuasan layanan pada siswa adalah perasaan yang dirasakan siswa ketika layanan bimbingan klasikal berlangsung. Siswa berhak memperoleh fasilitas ataupun sarana prasarana yang ada di sekolah dengan maksimal sehingga dapat terwujudnya layanan bimbingan klasikal yang menarik, kreatif, inovatif dan variatif.

Layanan bimbingan klasikal seringkali membuat bosan dan malas memerhatikan penjelasan guru bimbingan dan konseling. Hal ini terjadi disebabkan oleh pembelajaran yang dilakukan oleh guru bimbingan dan konseling yang monoton, metode pembelajaran kurang bervariasi, dan kurangnya pemanfaatan teknologi media yang ada di sekolah. Jika hal ini terjadi, akan menurunkan kepuasan siswa dan berkurangnya antusias siswa dalam mengikuti layanan bimbingan klasikal. Seperti yang diungkapkan oleh salah satu siswa, 
mengatakan jika layanan bimbingan klasikal terasa membosankan sehingga siswa merasa tidak puas dan bosan dengan layanan yang diberikan oleh guru bimbingan dan konseling.

MTs Negeri 6 Sleman dipilih sebagai tempat penelitian ini karena di sekolah tersebut telah terdapat teknologi media seperti di setiap kelas sudah terdapat fasilitas LCD proyektor. Selain itu, di dalam ruang bimbingan dan konseling sudah terdapat komputer untuk membantu kinerja guru bimbingan dan konseling. Media yang berkaitan dengan bimbingan dan konseling juga terlihat dari adanya poster, papan bimbingan, dan media lainnya.

Penelitian ini lebih menekankan pada penggunaan teknologi media bimbingan dan konseling dengan kepuasan layanan bimbingan klasikal siswa. Pada saat melakukan observasi, siswa lebih tertarik saat layanan bimbingan klasikal dengan memanfaatkan teknologi media yang saat itu menggunakan laptop dan LCD proyektor. Siswa sangat senang apabila layanan bimbingan klasikal dengan memanfaatkan teknologi media. Apalagi ditambah kreativitas dalam pembuatan materi dengan disisipkan video ataupun film yang mendidik, seperti yang diungkapkan oleh guru bimbingan dan konseling, mengatakan bahwa siswa sangat tertarik apabila pembelajaran dilakukan menggunakan media, apalagi ditambah dengan pemutaran film ataupun video yang sangat memotivasi. Siswa akan lebih fokus untuk belajar dan selalu memperhatikan materi yang disampaikan guru bimbingan dan konseling. Di sisi lain, siswa juga merasa lebih enak dan lebih paham jika layanan bimbingan klasikal menggunakan media.

Maka dari itu, peneliti tertarik untuk melakukan penelitan tentang hubungan antara penggunaan teknologi media bimbingan dan konseling dengan kepuasan layanan bimbingan klasikal siswa kelas VIII MTs Negeri 6 Sleman. Dengan demkian tujuan dari penelitian ini adalah untuk mengetahui adanya hubungan antara penggunaan teknologi media bimbingan dan konseling dengan kepuasan layanan bimbingan klasikal siswa kelas VIII MTs Negeri 6 Sleman.

\section{METODE}

Hipotesis pada penelitian ini adalah terdapat hubungan positif dan signifikan antara penggunaan teknologi media bimbingan dan konseling dengan kepuasan layanan bimbingan klasikal siswa. Yang berarti semakin tinggi penggunaan teknologi media bimbingan dan konseling semakin tinggi pula kepuasan layanan bimbingan klasikal siswa. 
Jenis penelitian yang digunakan adalah metode kuantitatif dengan model korelasi. Penelitian korelasional merupakan suatu tipe penelitian yang melihat hubungan antara satu atau beberapa ubahan dengan satu atau beberapa ubahan yang lain. Metode korelasi adalah suatu penelitian dengan karakteristik masalah berupa hubungan korelasi antara dua variabel atau lebih. Variabel dalam penelitian ini adalah penggunaan teknologi media bimbingan dan konseling sebagai variabel bebas, dan kepuasan layanan bimbingan klasikal siswa sebagai variabel terikat.

Terdapat dua skala yang dikembangkan untuk mengetahui hubungan antara penggunaan teknologi media bimbingan dan konseling dengan kepuasan layanan bimbingan klasikal siswa adalah model skala Likert dengan empat alternatif jawaban. Pertama, penggunaan teknologi media bimbingan dan konseling diukur dengan skala penggunaan teknologi media bimbingan dan konseling berdasarkan teori Mochamad Nursalim, yaitu memperjelas pesan, mengatasi keterbatasan, menimbulkan minat siswa, memberi rangsangan yang sama, proses layanan bimbingan dan konseling lebih menarik, proses layanan bimbingan dan konseling lebih interaktif, kualitas layanan bimbingan dan konseling meningkat, dan meningkatkan sikap positif siswa. ${ }^{1}$ Skor yang diperoleh dari skala ini akan menunjukkan tingkat penggunaan teknologi media bimbingan dan konseling. Semakin tinggi skor yang diperoleh maka semakin tinggi untuk menggunakan teknologi media bimbingan dan konseling.

Kedua, kepuasan layanan bimbingan klasikal siswa diukur dengan skala kepuasan layanan bimbingan klasikal berdasarkan teori Purwa Udiutomo yang diadaptasi dari penelitian milik Ati Puji Rahayu meliputi metode pembelajaran yang tepat dan sesuai, media pembelajaran yang menarik dan bervariasi, performansi guru yang optimal, dan evaluasi pembelajaran yang objektif. ${ }^{2}$ Skor

\footnotetext{
${ }^{1}$ Mochamad Nursalim, Pengembangan Media Bimbingan dan Konseling, (Jakarta Barat: Akademia Permata. 2013), hlm. 7.

${ }^{2}$ Ati Puji Rahayu, Korelasi antara Kepuasan Siswa terhadap Pembelajaran Mahasiswa Magang III Jurusan PAI tahun 2016 Fakultas Ilmu Tarbiyah dan Keguruan UIN Sunan Kalijaga dengan Motivasi Belajar PAI Siswa SMP Negeri 1 Pleret Bantul, Skripsi, (Yogyakarta: Jurusan 
yang diperoleh dari skala ini akan menunjukkan tingkat kepuasan layanan bimbingan klasikal siswa. Semakin tinggi skor yang diperoleh maka semakin tinggi kepuasan layanan bimbingan klasikal.

Populasi pada penelitian ini adalah seluruh siswa kelas VIII di MTs Negeri 6 Sleman yang berjumlah 165 siswa. Sampling yang digunakan pada penelitian ini adalah probability sampling dengan teknik cluster random sampling, yang berarti melakukan randomisasi terhadap kelompok, bukan terhadap individu. ${ }^{3}$ Kelompok di sini ialah kelas-kelas yang mempunyai hak sama untuk menjadi sampel penelitian. Untuk mendapatkan sampel tersebut, maka peneliti mengacak kelas yaitu VIII A, VIII B, VIII C, VIII D, dan VIII E dengan asumsi bahwa kelas yang terpilih mewakili populasi. Dari pengundian yang telah dilakukan maka diperoleh jumlah siswa untuk sampel penelitian sebanyak 66 siswa dan sampel uji coba sebanyak 65 siswa.

\section{HASIL}

1. Uji Validitas

Teknik validitas korelasi dalam penelitian ini menggunakan rumus korelasi product moment dari Pearson dengan bantuan SPSS 16.0 for Windows. Korelasi ini digunakan untuk menentukan hubungan antara dua gejala interval. ${ }^{4}$ Dalam penentuan layak atau tidaknya suatu item yang akan digunakan, biasanya dilakukan uji signifikansi koefisien korelasi pada taraf signifikansi 0,05 , artinya suatu item dianggap valid jika berkorelasi signifikan terhadap skor total. Atau jika melakukan penilaian langsung terhadap koefisien korelasi, bisa digunakan batas minimal korelasi 0,30. Semua item yang mencapai koefisien korelasi minimal 0,30 daya pembedanya dianggap memuaskan. Tetapi bila jumlah item belum mencukupi bisa menurunkan

Pendidikan Agama Islam Fakultas Ilmu Tarbiyah dan Keguruan UIN Sunan Kalijaga, 2017), hlm. 29.

${ }^{3}$ Saifuddin Azwar, Metode Penelitian Suatu Pendekatan, (Yogyakarta: Rineka Cipta, 2008), hlm. 87.

${ }^{4}$ Suharsimi Arikunto, Prosedur Penelitian: Suatu Pendekatan Praktik, (Jakarta: PT Rineka Cipta, 2010),hlm. 255. 
sedikit batas kriteria 0,30 menjadi 0,25 tetapi menurunkan batas kriteria di bawah 0,20 sangat tidak disarankan. ${ }^{5}$

Dalam penelitian ini, peneliti melakukan uji coba ke dua kelas yaitu kelas A sebanyak 33 siswa dan E sebanyak 30 siswa. Hasil analisis item dari 30 item pada skala penggunaan teknologi media bimbingan dan konseling yang telah disusun diperoleh hasil korelasi item yang bergerak dari 0,3030,633 maka diperoleh 26 item yang shahih dan 4 item yang gugur. Sedangkan hasil analisis item dari 40 item pada skala kepuasan layanan bimbingan klasikal yang telah disusun diperoleh hasil korelasi item yang bergerak dari 0,300-0,666 maka diperoleh 33 item yang shahih dan 7 item yang gugur.

2. Uji Reliabilitas

Dalam mengetahui sejauhmana hasil suatu pengukuran dapat dipercaya harus dilakukan uji reliabilitas alat ukur. Dalam mengukur reliabilitas alat ukur, kaidah yang dipakai apabila > dari 0.6 maka dapat disimpulkan bahwa instrumen tersebut dikatakan reliabel, dan apabila < dari 0.6 maka dapat dikatakan tidak reliabel.

Tabel 1. Jumlah Item Valid dan Nilai Reliabilitas Setiap Variabel

\begin{tabular}{lccc}
\hline \multicolumn{1}{c}{ Variabel } & $\begin{array}{c}\text { Jumlah Item } \\
\text { Awal }\end{array}$ & $\begin{array}{c}\text { Jumlah Item } \\
\text { Valid }\end{array}$ & $\begin{array}{c}\text { Nilai } \\
\text { Reliabilitas }\end{array}$ \\
\hline $\begin{array}{l}\text { Penggunaan Teknologi Media } \\
\text { Bimbingan dan Konseling }\end{array}$ & 30 & 26 & 0.900 \\
\hline $\begin{array}{l}\text { Kepuasan Layanan Bimbingan } \\
\text { Klasikal }\end{array}$ & 40 & 33 & 0,897 \\
\hline
\end{tabular}

Berdasarkan hasil yang diperoleh nilai koefisien reliabilitas skala penggunaan teknologi media bimbingan dan konseling sebesar 0,900 dan skala kepuasan layanan bimbingan klasikal sebesar 0,897 dimana hasil tersebut menunjukkan > 0.6. Maka dari itu dapat disimpulkan skala penelitian reliabel atau konsisten, sehingga dapat digunakan untuk instrumen penelitian.

3. Uji Normalitas

Uji normalitas dalam penelitian ini dilakukan teknik One Sample Kolmogorov Smirnov Test dan pengolahannya menggunakan SPSS 16.0 for

\footnotetext{
${ }^{5}$ Saifuddin Azwar, Reliabilitas dan Validitas, (Yogyakarta: Pustaka Pelajar, 2011), hlm. 158. 
Windows. Kaidah yang digunakan untuk mengetahui normal atau tidak data tersebut jika p $>0.05$ maka data tersebut normal. Sebaliknya, jika $\mathrm{p}<0.05$ maka data tersebut tidak normal. ${ }^{6}$

Diperoleh hasil 0,775 untuk variabel penggunaan teknologi media bimbingan dan konseling serta hasil 0,595 untuk variabel kepuasan layanan bimbingan klasikal. Artinya 0,775 >0,05 untuk variabel penggunaan teknologi media bimbingan dan konseling serta 0,595>0,05 untuk variabel kepuasan layanan bimbingan klasikal.

Dari hasil uji normalitas menunjukkan bahwa harga One Sample Kolmogorov smirnov Test masing-masing di atas nilai probabilitas sehingga distribusi skor kedua variabel adalah normal.

4. Uji Linearitas

Uji linearitas dilakukan untuk mengetahui status linear atau tidaknya suatu distribusi data penelitian dengan menggunakan nilai signifikansi 0,05. Apabila dalam uji linearitas diperoleh nilai signifikan $\mathrm{F} \geq 0,05$ maka terdapat hubungan linear secara signifikan antar variabel. Setelah melakukan uji linearitas maka diperoleh hasil nilai signifikansi sebesar 0,932 Dari hasil tersebut, diketahui bahwa nilai signifikansi 0,932>0,05 yang artinya terdapat hubungan linear secara signifikan antara variabel penggunaan teknologi media bimbingan dan konseling $(\mathrm{X})$ dengan kepuasan layanan bimbingan klasikal (Y).

5. Uji Hipotesis

Uji hipotesis menggunakan analisis korelasi Product Moment dari Pearson dengan bantuan SPSS 16.0 for Windows, dengan hasil sebagai berikut:

Tabel 2. Hasil Uji Hipotesis

\begin{tabular}{lcc}
\hline \multicolumn{1}{c}{ Variabel } & $\begin{array}{c}\text { Pearson Correlation } \\
\left(\mathbf{r}_{\mathbf{x y}}\right)\end{array}$ & Sig. (2-tailed) atau p \\
\hline $\begin{array}{l}\text { Penggunaan Teknologi Media } \\
\text { Bimbingan dan Konseling }\end{array}$ & 0,406 & 0,001 \\
\hline Kepuasan Layanan Bimbingan & 0,406 & 0,001 \\
\hline
\end{tabular}

${ }^{6}$ Nur Aeni Sanjaya, Hubungan antara Bimbingan Pribadi dengan Asertivitas Siswa Kelas VIII MTs N Yogyakarta 1, Skripsi, (Yogyakarta: Jurusan Bimbingan dan Konseling Islam Fakultas Dakwah dan Komunikasi, UIN Sunan Kalijaga, 2017), hlm. 61. 
Dari tabel di atas dapat diketahui bahwa $\mathrm{r}_{\mathrm{xy}}$ sebesar 0,406 dan sig. (2tailed) atau $\mathrm{p}=0,001$ pada taraf $1 \%$. Hal ini berarti nilai $\mathrm{p}$ lebih kecil dari 0,01 sehingga dapat dinyatakan sangat signifikan. Dengan $r x y=0,406$ dan $p=0,001$ maka hipotesis penelitian, yaitu hubungan yang positif dan signifikan antara penggunaan teknologi media bimbingan dan konseling dengan kepuasan layanan bimbingan klasikal siswa kelas VIII MTs Negeri 6 Sleman dinyatakan diterima dan teruji kebenarannya. Hasil uji hipotesis menunjukkan terdapat hubungan yang positif dengan angka rxy $=0,406$ dan $p=0,001<0,01$ yang menunjukkan hubungan yang sangat signifikan antara penggunaan teknologi media bimbingan dan konseling dengan kepuasan layanan bimbingan klasikal.

\section{PEMBAHASAN}

Hasil penelitian menunjukkan bahwa ada hubungan positif dan sangat signifikan antara penggunaan teknologi media bimbingan dan konseling dengan kepuasaan layanan bimbingan klasikal siswa kelas VIII MTs Negeri 6 Sleman. Artinya, semakin tinggi penggunaan teknologi media bimbingan dan konseling maka semakin tinggi pula kepuasan layanan bimbingan klasikal. Sebaliknya, semakin rendah penggunaan teknologi media bimbingan dan konseling maka semakin rendah pula kepuasan layanan bimbingan klasikal. Penggunaan teknologi media bimbingan dan konseling adalah segala sesuatu yang menjadi sarana prasarana yang digunakan oleh guru bimbingan dan konseling untuk membantu melaksanakan layanan bimbingan dan konseling sehingga meningkatkan ketertarikan siswa untuk belajar demi mencapai tujuan yang diinginkan.

Dilihat dari pengertian di atas penggunaan teknologi media bimbingan dan konseling memiliki peranan penting untuk meningkatkan kepuasan layanan bimbingan klasikal siswa. Dalam peranan ini penggunaan teknologi media bimbingan dan konseling membantu siswa dalam ketertarikan untuk belajar dalam layanan bimbingan klasikal. Ketertarikan untuk belajar berkaitan dengan munculnya semangat siswa dalam pembelajaran sehari-hari didalam kelas yang 
pada akhirnya memunculkan kepuasan siswa. Individu yang memiliki kepuasan dalam layanan bimbingan klasikal akan mendorong seseorang untuk fokus dalam belajar.

Senada dengan yang dipaparkan oleh guru bimbingan dan konseling tentang hubungan antara penggunaan teknologi media bimbingan dan konseling dengan kepuasan layanan bimbingan klasikal siswa. Hasil wawancara menunjukkan bahwa teknologi media sangat mendukung layanan bimbingan klasikal untuk menarik ketertarikan siswa dalam layanan bimbingan dan konseling. Siswa menjadi lebih semangat, termotivasi dan fokus terhadap materi yang disampaikan guru bimbingan dan konseling. Dalam layanan bimbingan klasikal yang dilakukan oleh guru bimbingan dan konseling, memang tidak selalu menggunakan teknologi media, salah satu metode lain yang digunakan adalah bercerita.

Peneliti juga mewawancarai beberapa siswa kelas VIII. Siswa merasa mudah memahami saat guru bimbingan dan konseling melakuan layanan bimbingan klasikal dengan menggunakan media. Penjelasan yang dipaparkan guru bimbingan dan konseling juga semakin menarik sehingga siswa merasa lebih asyik dalam mengikuti pembelajaran. Dapat diketahui bahwa penggunaan teknologi media bimbingan dan konseling dapat mempengaruhi kepuasan layanan bimbingan klasikal siswa. Siswa merasa lebih mudah memahami materi saat guru bimbingan dan konseling menyampaikan dengan media.

\section{KESIMPULAN}

Hasil penelitian ini terdapat hubungan yang positif dan sangat signifikan antara penggunaan teknologi media bimbingan dan konseling dengan kepuasan layanan bimbingan klasikal siswa kelas VIII MTs Negeri 6 Sleman dengan nilai korelasi sebesar 0,406 pada taraf signifikan 1\%. Semakin tinggi penggunaan teknologi media bimbingan dan konseling maka semakin tinggi pula kepuasan layanan bimbingan klasikal. Sebaliknya, jika semakin rendah penggunaan teknologi media bimbingan dan konseling maka semakin rendah pula kepuasan layanan bimbingan klasikal. 
Hasil penelitian tersebut juga didukung juga dengan hasil wawancara dengan guru bimbingan dan konseling serta siswa, dapat disimpulkan bahwa penggunaan teknologi media bimbingan dan konseling merupakan salah satu cara untuk meningkatkan kepuasan layanan bimbingan klasikal siswa. Penggunaan teknologi media bimbingan dan konseling diperlukan oleh siswa untuk mempermudah memahami materi yang disampaikan saat layanan bimbingan klasikal. Dari layanan bimbingan klasikal yang diberikan guru bimbingan dan konseling tersebut siswa dapat merasa lebih semangat.

Guru bimbingan dan konseling dalam melaksanakan layanan bimbingan klasikal dapat lebih sering menggunakan teknologi media yang dibuat secara menarik agar siswa lebih fokus dan tertarik untuk mengikuti kegiatan tersebut. Di samping itu, guru bimbingan dan konseling dapat melihat langsung bagaimana antusias siswa dalam mengikuti layanan bimbingan klasikal. Selanjutnya, guru bimbingan dan konseling perlu melakukan tindak lanjut bagi siswa yang memerlukan bantuan dalam mengatasi masalah belajar. Sehingga, guru bimbingan dan konseling dapat lebih menumbuhkan rasa kepedulian terhadap siswa.

Pentingnya penggunaan teknologi media bimbingan dan konseling dalam layanan bimbingan klasikal adalah guna membantu siswa dalam memahami materi dengan lebih baik. Selain itu penggunaan teknologi media bimbingan dan konseling dapat menumbuhkan semangat belajar siswa. Siswa dapat merasakan nilai positif dari penggunaan teknologi media bimbingan dan konseling. Kepuasan siswa dalam mengikuti layanan bimbingan klasikal menjadi lebih baik apabila dibantu teknologi media.

\section{DAFTAR PUSTAKA}

Arikunto, Suharsimi. (2010). Prosedur Penelitian: Suatu Pendekatan Praktik. Jakarta: PT Rineka Cipta. . (1998). Prosedur Penelitian Suatu Pendekatan Praktek. Jakarta: PT Rineka Cipta.

Azwar, Saifuddin. (2011). Reliabilitas dan Validitas. Yogyakarta: Pustaka Pelajar. 

(2008). Metode Penelitian Suatu Pendekatan. Yogyakarta: Rineka Cipta.

Departemen Pendidikan dan Kebudayaan Republik Indonesia. (2005). Kamus Besar Bahasa Indonesia. Jakarta: Balai Pustaka.

Hakim, Ali Lukmanul. (2014). Kepuasan Siswa terhadap Layanan Bimbingan Konseling di SMK Al-Hidayah Lestari Lebak Bulus (Skripsi). Jakarta: Jurusan Manajemen Pendidikan Fakultas Ilmu Tarbiyah dan Keguruan UIN Syarif Hidayatullah.

Nursalim, Mochamad. (2013). Pengembangan Media Bimbingan dan Konseling. Jakarta Barat: Akademia Permata.

Rahayu, Ati Puji. (2017). Korelasi antara Kepuasan Siswa terhadap Pembelajaran Mahasiswa Magang III Jurusan PAI tahun 2016 Fakultas Ilmu Tarbiyah dan Keguruan UIN Sunan Kalijaga dengan Motivasi Belajar PAI Siswa SMP Negeri 1 Pleret Bantul (Skripsi). Yogyakarta: Jurusan Pendidikan Agama Islam Fakultas Ilmu Tarbiyah dan Keguruan UIN Sunan Kalijaga

Sanjaya, Nur Aeni. (2017). Hubungan antara Bimbingan Pribadi dengan Asertivitas Siswa Kelas VIII MTs $N$ Yogyakarta 1 (Skripsi). Yogyakarta: Jurusan Bimbingan dan Konseling Islam Fakultas Dakwah dan Komunikasi UIN Sunan Kalijaga.

Siregar, Sofyan. (2013). Metode Penelitian Kuantitatif. Jakarta: Kencana.

Sugiyono. (2012). Metode Penelitian Pendidikan (Pendekatan Kuantitatif, Kualitatif, dan $R \& D)$. Bandung: Alfabeta.

Sujoko. (2013). Pemanfaatan Teknologi Informasi dan Komunikasi sebagai Media Pembelajaran di SMP Negeri 1 Geger Madiun. Madiun: Jurnal Kebijakan dan Pengembangan Pendidikan. Vol. 1: 1.

Sunyoto, Danang. (2013). Teori, Kuesioner dan Analisis Data untuk Pemasaran dan Perilaku Konsumen. Yogyakarta: Graha Ilmu.

Yusuf, A. Muri. (2014). Metode Penelitian: Kuantitatif, Kualitatif, dan Penelitian Gabungan. Jakarta: Prenadamedia. 